\title{
‡USGS
}

science for a changing world

Prepared for the National Aeronautics and Space Administration

\section{Geologic Map of the Themis Regio Quadrangle (V-53), Venus}

\author{
By Ellen R. Stofan and Antony W. Brian
}

Pamphlet to accompany

Scientific Investigations Map 3165

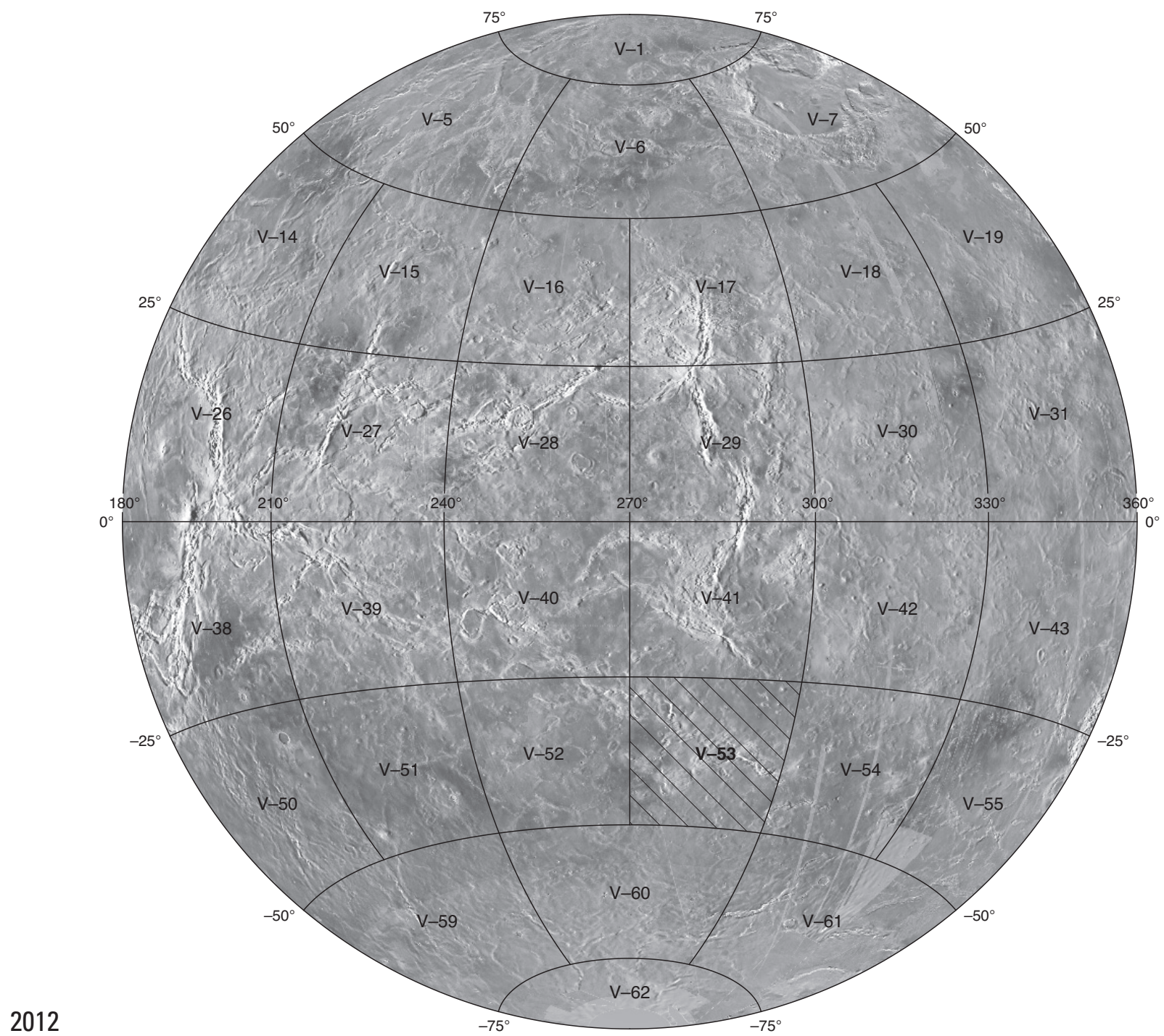

U.S. Department of the Interior

U.S. Geological Survey 
This page intentionally left blank 


\section{Contents}

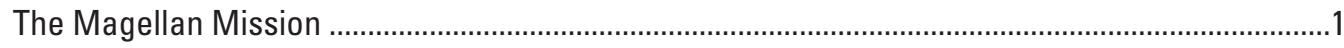

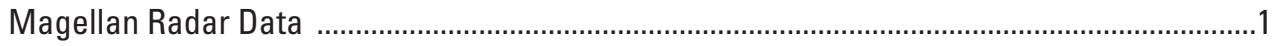

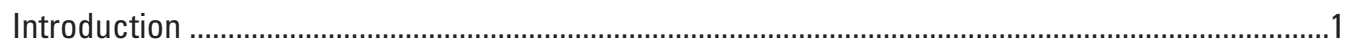

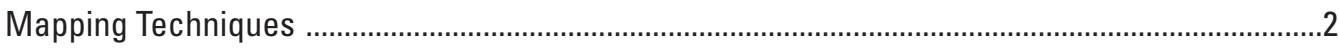

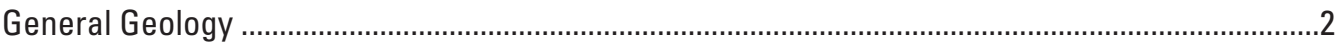

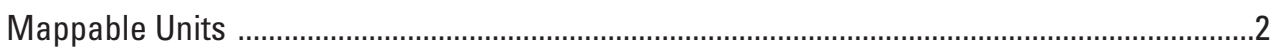

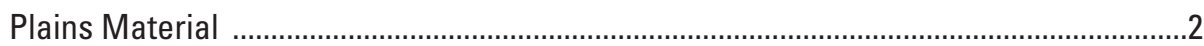

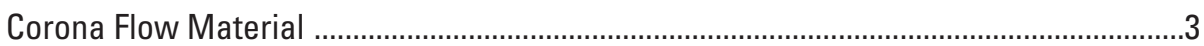

Volcanic Edifice and Flow Material ................................................................................

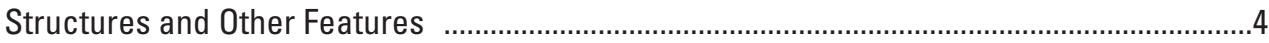

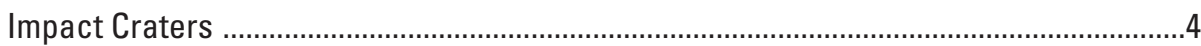

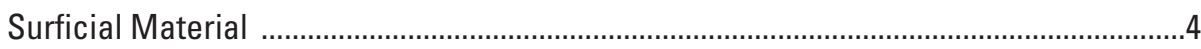

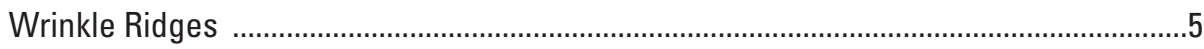

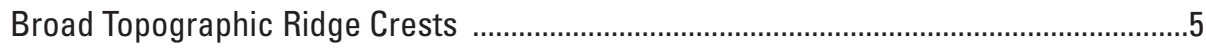

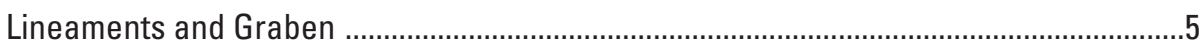

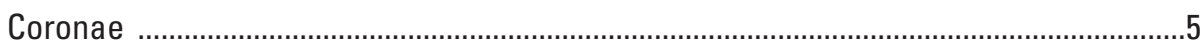

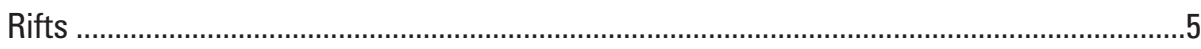

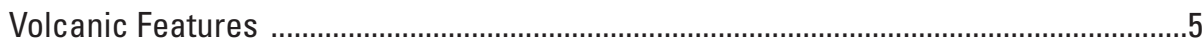

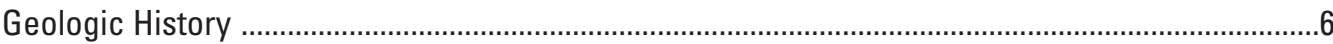

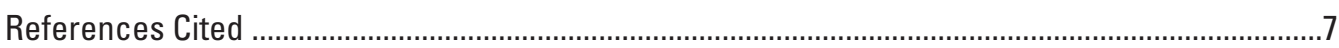

\section{Tables}

1. Coronae that produced deposits mapped in the Themis Regio quadrangle (V-53), Venus. .....10

2. Impact craters of Themis Regio quadrangle (V-53), Venus. ...................................................11

3. Volcanoes of Themis Regio quadrangle (V-53), Venus. ........................................................11

4. Tabular version of the map unit relations in the Themis Regio quadrangle (V-53), Venus. ......12

\section{Figures}

1. Sketch map of major features in Themis Regio quadrangle (V-53), Venus, shown on base image (map sheet)

2. Magellan topographic data of Themis Regio quadrangle (V-53), Venus (map sheet)

3. Magellan rms slope map of Themis Regio quadrangle (V-53), Venus (map sheet)

4. Magellan Fresnel reflectivity data for Themis Regio quadrangle (V-53), Venus (map sheet)

5. Magellan SAR image of an unnamed channel on unit pm in Themis Regio quadrangle (V-53), Venus (map sheet)

6. Magellan SAR image of east-central Themis Regio quadrangle (V-53), Venus (map sheet)

7. Magellan SAR image of northwestern Themis Regio quadrangle (V-53), Venus (map sheet) 
This page intentionally left blank 


\section{The Magellan Mission}

The Magellan spacecraft orbited Venus from August 10, 1990, until it plunged into the Venusian atmosphere on October 12, 1994. Magellan Mission objectives included (1) improving the knowledge of the geological processes, surface properties, and geologic history of Venus by analysis of surface radar characteristics, topography, and morphology and (2) improving the knowledge of the geophysics of Venus by analysis of Venusian gravity.

The Magellan spacecraft carried a $12.6-\mathrm{cm}$ radar system to map the surface of Venus. The transmitter and receiver systems were used to collect three data sets: (1) synthetic aperture radar (SAR) images of the surface, (2) passive microwave thermal emission observations, and (3) measurements of the backscattered power at small angles of incidence, which were processed to yield altimetric data. Radar imaging and altimetric and radiometric mapping of the Venusian surface were accomplished in mission cycles 1, 2, and 3 from September 1990 until September 1992. Ninety-eight percent of the surface was mapped with radar resolution on the order of $120 \mathrm{~m}$. The SAR observations were projected to a 75-m nominal horizontal resolution, and these full-resolution data compose the image base used in geologic mapping. The primary polarization mode was horizontal-transmit, horizontal-receive $(\mathrm{HH})$, but additional data for selected areas were collected for the vertical polarization sense. Incidence angles varied between about $20^{\circ}$ and $45^{\circ}$.

High-resolution Doppler tracking of the spacecraft took place from September 1992 through October 1994 (mission cycles 4, 5, 6). Approximately 950 orbits of high-resolution gravity observations were obtained between September 1992 and May 1993 while Magellan was in an elliptical orbit with a periapsis near $175 \mathrm{~km}$ and an apoapsis near 8,000 km. An additional 1,500 orbits were obtained following orbit-circularization in mid-1993. These data exist as a $75^{\circ}$ by $75^{\circ}$ harmonic field.

\section{MAGELLAN RADAR DATA}

Radar backscatter power is determined by (1) the morphology of the surface at a broad range of scales and (2) the intrinsic reflectivity, or dielectric constant, of the material. Topography at scales of several meters and larger can produce quasi-specular echoes, and the strength of the return is greatest when the local surface is perpendicular to the incident beam. This type of scattering is most important at very small angles of incidence, because natural surfaces generally have few large tilted facets at high angles. The exception is in areas of steep slopes, such as ridges or rift zones, where favorably tilted terrain can produce very bright signatures in the radar image. For most other areas, diffuse echoes from roughness at scales comparable to the radar wavelength are responsible for variations in the SAR return. In either case, the echo strength is also modulated by the reflectivity of the surface material. The density of the upper few wavelengths of the surface can have a significant effect. Low-density layers, such as crater ejecta or volcanic ash, can absorb the incident energy and produce a lower observed echo. On Venus, a rapid increase in reflectivity exists at a certain critical elevation above which high-dielectric minerals or coatings are thought to be present. This leads to very bright SAR echoes from virtually all areas above that critical elevation.

The measurements of passive thermal emission from Venus, though of much lower spatial resolution than the SAR data, are more sensitive to changes in the dielectric constant of the surface than to roughness. They can be used to augment studies of the surface and to discriminate between roughness and reflectivity effects. Observations of the near-nadir backscatter power, collected using a separate smaller antenna on the spacecraft, were modeled using the Hagfors expression for echoes from gently undulating surfaces to yield estimates of planetary radius, Fresnel reflectivity, and root-mean-square (rms) slope. The topographic data produced by this technique have horizontal footprint sizes of about $10 \mathrm{~km}$ near periapsis and a vertical resolution on the order of $100 \mathrm{~m}$. The Fresnel reflectivity data provide a comparison to the emissivity maps, and the rms slope parameter is an indicator of the surface tilts, which contribute to the quasi-specular scattering component.

\section{Introduction}

The Themis Regio quadrangle (V-53), Venus, has been geologically mapped at 1:5,000,000 scale as part of the NASA Planetary Geologic Mapping Program. The quadrangle extends from lat $25^{\circ}$ to $50^{\circ} \mathrm{S}$. and from long $270^{\circ}$ to $300^{\circ} \mathrm{E}$. and encompasses the Themis Regio highland, the surrounding plains, and the southernmost extension of Parga Chasmata. Themis Regio is a broad regional topographic high with a diameter of about $2,000 \mathrm{~km}$ and a height of about $0.5 \mathrm{~km}$ that has been interpreted previously as a hotspot underlain by a mantle plume (Stofan and others, 1995). The Themis rise is dominated by coronae and lies at the terminus of the Parga Chasmata corona chain (Stofan and others, 1992, 1995) (fig. 1). Themis Regio is the only one of the three corona-dominated rises that contains significant extensional deformation (Stofan and others, 1995). Fractures and grabens are much less common than along the rest of Parga Chasmata and are embayed by corona-related flows in places. Rift and corona formation has overlapped in time at Themis Regio (Martin and others, 2007).

The overall topography of the map area consists of lowlying plains, lying slightly below the mean planetary radius (MPR, 6051.84 km, Ford and Pettengill, 1992) and surrounding the Themis Regio highland (fig. 2). The highest point in the quadrangle, at $6,054.25 \mathrm{~km}$, is found in the interior of Shiwanokia Corona (lat $42^{\circ} \mathrm{S}$., long $277^{\circ} \mathrm{E}$.); the lowest points are found along the Parga Chasmata rift and in the troughs around Tacoma Corona at about $1 \mathrm{~km}$ below MPR (for example, lat $38^{\circ} \mathrm{S}$., long $240^{\circ} \mathrm{E}$.; lat $38^{\circ} \mathrm{S}$., long $292.5^{\circ} \mathrm{E}$.). The roughest regions in the quadrangle occur in the rim and trough regions of Semiramus and Ukemochi Coronae $\left(\sim 7.5^{\circ} \mathrm{rms}\right.$ slope $)$, but most of the map area is relatively smooth (comparable to the average Venus rms slope value of $2.84^{\circ}$ of Ford and Pettengill, 1992) (fig. 3). Fresnel reflectivity values in the map area do not vary greatly, except for small areas within the interiors of Shiwanokia and Shulamite Coronae, where values are as high 
as 0.23 . The lowest reflectivity $(0.05)$ occurs in the plains to the southwest of Shiwanokia Corona (fig. 4). The Visual and Infrared Spectrometer instrument on the Venus Express spacecraft (Helbert and others, 2008) measured high emissivity in the $1 \mathrm{~mm}$ range at several coronae and large volcanoes in the map area, including at Mielikki Mons and Shulamite and Shiwanokia Coronae (Smrekar and others, 2010). The high emissivity values indicate that these flows are unweathered and, therefore, relatively young $(<250,000 \mathrm{yr})$ (Smrekar and others, 2010).

The map area includes twenty-five coronae (table 1, fig. 1), as well as deposits from Bibi-Patma Corona, which is primarily located in the Nepthys Mons quadrangle (V-54). Thirteen coronae are on the Themis highland, with six in the surrounding plains or the rift leading into Themis Regio. The area covered by this quadrangle is part of the Beta, Atla, and Themis Regiones (BAT), which contains an unusually high concentration of volcanic features (Crumpler and others, 1997). Twelve impact craters are in the quadrangle (table 2). Other major features include the Parga Chasmata rift in the northwest corner of the quadrangle and six volcanoes greater than $100 \mathrm{~km}$ in diameter (table 3). Seven steep-sided domes are also located within the Themis Regio quadrangle.

\section{Mapping Techniques}

The geologic map of the Themis Regio quadrangle (V-53) was constructed using standard planetary geologic mapping techniques (Wilhelms, 1972, 1990). The base map is composed of Magellan synthetic aperture radar (SAR) data. Synthetic parallax stereo images with a 10x vertical exaggeration, produced by the U.S. Geological Survey (USGS) at Flagstaff, Ariz., were used extensively to determine stratigraphic relations. Additional information on map units was provided by Magellan altimetry, roughness, reflectivity, and emissivity data sets (Pettengill and others, 1992; Campbell, 1995).

Full-resolution Magellan image mosaics (FMaps) produced by the USGS were used extensively in mapping. Unit characteristics and boundary locations that were not resolvable at C1-MIDR scale ( $225 \mathrm{~m} /$ pixel) were clearly seen at FMap scale (75 m/pixel) (actual radar resolution is about $120 \mathrm{~m}$ ). On the map, a solid line is used for a contact that is confidently located; a dashed contact is used where either the data resolution or surface expression of the units results in an approximately located unit boundary. Stratigraphic relations were best resolved utilizing the combination of large-format FMap prints, digital FMap data, and synthetic stereo data, although age relations were determined as a function of the scale and nature of the radar data utilized. Spatial resolution of data affects the ability to determine feature origin and age (Zimbelman, 2001); age relations between units and their mechanism(s) of formation in the map area are thus limited by the inherent resolution of the Magellan data.

The Correlation of Map Units does not show a broad range of ages, because unit relations do not clarify relative unit ages. For example, Rohina, Justitia, Angerona, and Kwannon Tholi and Tefnut and Mertseger Montes are shown as the same age, because they are in contact with a range of units but no units are younger. Therefore, they are shown as similar ages, but their actual ages may vary greatly. In addition, age relations of units that interfinger are difficult to represent on the Correlation of Map Units and are discussed in more detail in the text below.

Radar data presents unique challenges to constructing a geologic map (Ford and others, 1993; Hansen, 2000). As in any geologic map, contacts are mapped where complete data supports the interpretation. In radar data, however, distinguishing adjacent lava flow fields may not be possible, because flows are likely to have relatively similar backscatter characteristics and also because the surface of a unit may change laterally. For example, in this map area corona and large volcano flow aprons are in some cases seen to be divided into very few units, or not subdivided at all, due to the lack of clearly mappable contacts that can be followed well enough to delineate a mappable flow unit. This should not be taken to indicate that flow material units associated with features such as Mielikki Mons or Durga Corona that are $>500 \mathrm{~km}$ across are actually made up of only one rock-stratigraphic unit, and caution should be used before interpreting these composite units as individual flow units (Romeo and Turcotte, 2009). In addition, structures tend to be more visible if they are oriented perpendicular to the radar look direction (Stofan and others, 1989). Therefore, in Magellan data, east-west-trending structures are likely to be less well represented in the data unless associated with rough talus slopes, while north-south-trending structures will be well defined.

Subunits (members) in the map area associated with a specific source are numbered, if stratigraphic relations between them could be determined (for example, units $\mathrm{fSe}_{1}$ and $\mathrm{fSe} \mathrm{e}_{2}$ ), or lettered, if not all members are in contact and, therefore, age relations are ambiguous (for example, units fTya, fTyb, $f \mathrm{fT}_{c}$, $\mathrm{fTy}$ ). Small volcanic edifices and structures in the map area are too numerous to be mapped individually at map scale (Tanaka, 1994); approximately one in ten features are shown, although fewer are mapped in the chasmata troughs where they are particularly dense.

\section{General Geology}

Five types of materials have been mapped in the Themis Regio quadrangle (V-53): plains, volcanic edifice and flow, corona, crater, and surficial materials. Materials are mapped as units, except for surficial material, which is shown by a stippled pattern. All types of material units occur throughout the quadrangle.

\section{Mappable Units}

\section{Plains Material}

We have identified seven plains-material units within the map area: densely fractured plains material (unit pdf), lineated plains material (unit pl), Themis Regio fractured plains material (unit pfT), mottled plains material (unit pm), Helen Planitia composite plains material (unit pcH), Themis Regio lobate 
plains material (unit pIT), and smooth plains material (unit ps) (table 4). Most of these plains units occur in relatively small patches $(<1,000 \mathrm{~km})$ and are composed of multiple smaller units that are grouped together to form a mappable unit. None of the plains units within this quadrangle are analogous to regionalscale plains units mapped in other quadrangles, such as the Aino composite plains material in Aino Planitia quadrangle (V-46) (Stofan and Guest, 2003). This is largely due to extensive resurfacing of much of the region by flows associated with coronae and volcanoes (Hansen and DeShon, 2002; Stofan and others, 2005). Plains units on Venus are generally interpreted to be volcanic in origin based on (1) the similarity to volcanic plains on other planets (Masursky and others, 1980; Barsukov and others, 1986), (2) the Venera lander surface chemical compositions and images (Surkov and others, 1984), and (3) the lack of water on the planet for at least 2-3 billion years (Kasting and Pollack, 1983), which make a sedimentary origin implausible.

The oldest plains units in the map area are the densely fractured plains material (unit pdf) and the lineated plains material (unit pl), both of which tend to be high standing and embayed by younger units. The two units are not in contact, so an age relation between them is not determinable, but they are always both the locally oldest units. In addition, these units may be a single time-stratigraphic unit or a mixture of different ages of kipukas of fractured plains. Unit pdf is very densely fractured and somewhat resembles tessera terrain mapped elsewhere on the planet, but it lacks the two or more orientations of structures typically characteristic of tessera terrain. Relative age relations between these and other units is shown in table 4.

The Themis Regio fractured plains material (unit pfT) is composed of multiple occurrences of heavily fractured plains on the Themis Regio volcanic rise. They may represent plains units off the rise that were elevated and deformed (such as units pm or ps), or they may represent earlier corona or volcano flows that have been subsequently deformed.

The mottled plains material (unit pm) is exposed in variably sized patches off the Themis Regio rise; one exposure is located on the northern margin of the rise north of Erigone Corona. It has a patchy or mottled appearance and is cut in places by fractures and wrinkle ridges. Not all occurrences of the unit are cut by wrinkle ridges, and the wrinkle-ridge sets do not have a consistent trend in all areas of the map (for example, they trend north in the southwest corner of the map and eastnortheast near the west-central edge of the map). Based on the unit's lobate boundaries and volcanic edifices, we interpret it to be composed of multiple materials of volcanic origin. The unit is also cut by two channels, Sinaan Vallis and a nearby unnamed channel at about lat $48^{\circ}-50^{\circ} \mathrm{S}$., long $272.5^{\circ} \mathrm{E}$., of probable volcanic origin (Baker and others, 1992; Komatsu and others, 1993). The channels are cut in places by wrinkle ridges. However, at one location, material from the channel appears to superpose wrinkle ridges, which suggests that multiple episodes of deformation have occurred (fig. 5). A few occurrences of unit pm are queried (lat $37.5^{\circ} \mathrm{S}$., long $275^{\circ} \mathrm{E}$.; lat $38^{\circ} \mathrm{S}$., long $276.5^{\circ} \mathrm{E}$.), because it is not certain whether the mapped unit is unit pm or unit pIT.

The Helen Planitia composite-flow plains material is made up of numerous lobate subunits of variable radar backscatter. It is interpreted to be volcanic in origin, from unidentified sources, based on the identification of diffuse flow fronts within the unit and its lobate boundaries. The Themis Regio lobate plains material (unit pIT) is mapped on the Themis Regio volcanic rise. Unit pIT has variable radar backscatter and lobate boundaries and is interpreted to be volcanic in origin. Within the unit, multiple flows can be discerned but are generally not mappable, and no sources can be identified. Different outcrops of this unit are not likely to be the same age; some may be volcanic flows that have originated from rift fractures, while others may have come from unknown edifices or coronae.

The youngest plains unit is smooth plains material (unit ps). The smooth plains unit (unit ps) forms extensive, generally featureless level plains. It is interpreted to be volcanic in origin based on its lobate boundaries, although no sources can be identified.

\section{Corona Flow Material}

Coronae are volcano-tectonic features that are interpreted to form over mantle upwellings owing to their associated volcanism and large size ( $>100 \mathrm{~km}$ across) and the raised topographic relief of many coronae (Basilevsky and others, 1986; Stofan and others, 1991; Koch and Manga, 1996). They have been classified according to morphology as concentric (circular), asymmetric (elongate or irregularly shaped), multiple, concentric/double ring (circular with a double annulus), or radial/ concentric (circular with dominant radial fractures) (table 1; Stofan and others, 1992). Twenty-three coronae have associated flow material units in the map area (tables 1, 4). Flows originate from the interior of coronae, as well as from the flanks and rim. Flows associated with coronae range in morphology from sheetlike to digitate, and both embay and are cut by corona-related deformation. Some of the coronae have multiple associated flow units, including Ukemochi Corona, with five associated units, and Tamiyo Corona, with four associated flow-material units. In addition, three additional coronae that are located within the quadrangle have no mapped units (table 1); they are strictly tectonic features that deform the materials of units in which they are located. These coronae are located on units pl (Partula Corona), pfT (Parvati Corona), and $\mathrm{fO}_{1}$ (Hutash Corona).

Some corona flows do overlap (table 4). Ikas Coronae flow material (unit fIk) is superposed by Nzambi flow material, member 2 (unit $\mathrm{fN}_{2}$ ), Tacoma Corona flow material (unit $\mathrm{fTa}$ ), Zwyie Corona flow material (unit fZ), Shulamite Corona flow material (unit fSh), Latta Corona flow material (unit $\mathrm{fLt}$ ), Semiramus Corona flow material, member 2 (unit fSe 2 ), and Shiwanokia Corona flow material, member 2 (unit fS 2 ). Shiwanokia Corona flow material, member 2 (unit $\mathrm{fS}_{2}$ ), flows also superpose Nzambi Corona flow material (unit $\mathrm{fN}_{2}$ ), Ama Corona flow material (unit fAm), and Shulamite Corona flow material (unit fSh). Tacoma Corona in turn is overlain by flow material from four other coronae. Several coronae have interfingered flows; Ukemochi Corona flow material, member a (unit $\mathrm{fU}_{\mathrm{a}}$ ), is superposed by Tamiyo Corona flow material, member a (unit fTya), but Ukemochi Corona flow material, member c (unit $f \mathrm{U}_{\mathrm{C}}$ ), is superposed on Tamiyo Corona flow material, member a (unit fTya). Similarly, Semiramus Corona flow mate- 
rial, member 1 (unit $\mathrm{fSe}_{1}$ ), is superposed by Tamiyo Corona flow material, member a (unit $\mathrm{fT}_{\mathrm{a}}$ ), and Semiramus Corona flow material, member 2 (unit $\mathrm{fSe}_{2}$ ), is superposed on Tamiyo Corona flow material, member a (unit fTya).

Four coronae have superposed impact craters (table 4). Jocelyn and Elza are on Obiemi Corona flow material, member 1 (unit $\mathrm{fO}_{1}$ ), Maret is superposed on Rigatona Corona flow material (unit fR), Bernadette is on Nzambi Corona flow material, member 2 (unit $\mathrm{fN}_{2}$ ), and Shiwanokia Corona flow material, member 2 (unit $\mathrm{fS}_{2}$ ), and Sabin is on Shiwanokia Corona flow material, member 1 (unit $\mathrm{fS}_{1}$ ).

A few coronae are in contact with volcanic and edifice flow materials. Chloris Mons flow material, members 1 and 2 (units $\mathrm{fC}_{1}$ and $\mathrm{fC}_{2}$ ), superpose Navolga Corona flow material (unit fNa), Nzambi Corona flow material, member 2 (unit $\mathrm{fN}_{2}$ ), Bibi-Patma Corona flow material, members $1-3$ (units $\mathrm{fB}_{1}, \mathrm{fB}_{2}$, $\mathrm{fB}_{3}$ ), Orbona Corona flow material (unit fOr), and Ukemochi Corona flow material, member e (unit $\mathrm{fU}_{\mathrm{e}}$ ). Tefnut Mons flow material (unit fTe) superposes Ukemochi Corona flow material, member c (unit $\mathrm{fU}_{\mathrm{C}}$ ), and Tamiyo Corona flow material, member a (unit fTya). Angerona Tholus flow material (unit $\mathrm{fAn}$ ) superposes Durga Corona flow material (unit fD), Rohina Tholus flow material (unit fRh) superposes Zywie Corona flow material (unit $f Z$ ), and Mertseger Mons flow material (unit fMe) superposes Obiemi Corona flow material, member 1 (unit $\mathrm{fO}_{1}$ ). Abeona Mons flow material (unit $\mathrm{fA}$ ) superposes Ama Corona flow material (unit fAm) but, in turn, is superposed by Shiwanokia Corona flow material, member 2 (unit $\mathrm{fS}_{2}$ ). Mielikki Mons flow material, member 2 (unit $\mathrm{fM}_{2}$ ), superposes Durga Corona flow material (unit fD), Anjea Corona flow material (unit fAj), and Rigatona Corona flow material (fR) but, in turn, is superposed by Gertjon Corona flow material, member 1 (fG1).

Coronae that have abundant associated flows are located both on and off the rift and on and off the volcanic rise. Recent work by Martin and others (2007) indicates that coronae on the Themis volcanic rise have more associated volcanism than other coronae in the Parga region. Along Parga Chasmata, coronae are located along the rift, as well as to the north and the south of the rift (Martin and others, 2007), similar to coronae along Hecate Chasma (Hamilton and Stofan, 1996). Most of the coronae in the map area formed synchronously with rifting, although some clearly predate the rifts and others postdate extensional deformation (Martin and others, 2007).

\section{Volcanic Edifice and Flow Material}

Thirteen units associated with eleven named volcanic edifices have been mapped, including those associated with the large volcanoes, Chloris Mons, Mielikki Mons, and Tefnut Mons (tables 3, 4). Some of the named edifices are tholi, defined as small domical hills or mountains (such as, Justitia Tholus).

Occurrences of volcanic center material (unit vc) and edifice field material (unit ef) are located throughout the map area. Although most volcanic center material or edifice field material outcrops have similar morphology, different occurrences of each have differing relations with surrounding units, indicating that they did not form at the same time. For example, Chloris Mons flow material, member 1 (unit $\mathrm{fC}_{1}$ ), is superposed by flow deposits from an edifice field but superposes deposits from a different edifice field. Volcanic center material consists of both large individual volcanic features, such as steep-sided domes and small unnamed volcanoes or small flow fields. The seven steep-sided domes in the map area are located in the plains, in the interior or on the rims of coronae, or at large volcanoes. They may represent more evolved compositions (McKenzie and others, 1992). However, their relatively smooth, fractured upper surfaces are not consistent with more silicic compositions, which would tend to form thick crusts that break into blocks (Stofan and others, 2000). Instead, they may be basaltic in composition and have early-stage crusts that were either annealed or entrained to form the final, relatively smooth upper dome surfaces (Stofan and others, 2000). Edifice field material consists of clusters of small edifices that have associated lava flows and outcrops ranging in size from $\sim 100$ to $400 \mathrm{~km}$ across (Head and others, 1992; Guest and others, 1992; Addington, 2001). The unit is mapped on the basis that the edifices share a common source and (or) are stratigraphically related.

Most of the volcanic flow units are not in contact with each other or with consistent plains or corona units, which makes the regional volcanic stratigraphy difficult to determine. The stratigraphic relations between coronae and volcanoes were discussed above. The only deposits associated with named volcanic edifices that are in contact are Siduri Mons flow materials (unit fSi) that are overlain by Chloris Mons flow material, member 1 (unit $\mathrm{fC}_{1}$ ).

\section{Structures and Other Features}

\section{Impact Craters}

There are twelve impact craters in the Themis Regio quadrangle (V-53) (tables 2, 4). They range from 11 to $52 \mathrm{~km}$ in diameter. Six have bright floors, three have completely dark floors, and three have small patches of dark material on their radar bright floors. Two craters, Peck and Bernadette, have a complex relation with the surrounding units. Peck appears to be superposed on unit pdf, but its ejecta has been fractured and embayed, and its interior has been embayed by later flows that occurred within unit pdf. Therefore, we interpret it to have formed during the apparently protracted evolution of unit pdf. The crater Bernadette is superposed on Nzambi Corona flow material, member 2 (unit $\mathrm{fN}_{2}$ ), but it is also embayed by small, difficult-to-map, later Nzambi flows. It is unclear if the flow that extends to the west of the crater and overlaps unit $\mathrm{fS}_{2}$, which we have mapped as part of Bernadette, is actually related to Bernadette or is a Nzambi-related flow.

\section{Surficial Material}

Radar-dark, diffuse material is mapped as surficial material (lat $41.5^{\circ} \mathrm{S}$., long $283^{\circ}$ E.). The material is superposed on Shulamite Corona flow material (unit fSh) and does not have an associated impact crater. We interpret this deposit to be the product of the breakup of an impactor in the atmosphere (Phillips and others, 1991). The resulting shock wave pulverizes the 
upper layers of the surface, producing a roughly circular region of impact debris (Phillips and others, 1991; Zahnle, 1992).

\section{Wrinkle Ridges}

Wrinkle ridges in the map area are tens of kilometers to a few hundred kilometers long, sinuous, and less than a few kilometers wide. Very few plains units in the map area are deformed by wrinkle ridges, which is similar to plains units in the Hecate Chasma quadrangle (V-28) (Stofan and others, 2012) to the northwest. In the southern region of the map area, some mapped north-northwest-trending wrinkle ridges deform units $\mathrm{pcH}$, pm, plT, and pfT. Near the west-central edge of the map area, east-northeast-trending ridges deform unit pm. Wrinkle ridges are common on plains units in other regions on Venus (Squyres and others, 1992; McGill, 1993) and are interpreted as forming from limited amounts of horizontal contraction (Plescia and Golombek, 1986).

\section{Broad Topographic Ridge Crests}

In several locations in the map area, we have indicated the location of broad topographic ridge crests, 10-20 km wide and several hundred kilometers long, that correspond to the raised topographic rims of Shiwanokia and Shulamite Coronae and a topographic ridge near the southern boundary of the map in unit $\mathrm{pcH}$.

\section{Lineaments and Graben}

Radar-bright, sharply defined straight lineaments that are distributed throughout the map area have lengths to several hundred kilometers and widths of a few kilometers. Graben are mapped where two parallel lineaments border a depression. We interpret most lineaments to be extensional in origin, given their overall morphology. Other nonrift-associated fractures in the map area are associated with coronae and volcanoes. In particular, several coronae and volcanoes have central radial sets of fractures that are interpreted to be the surface expression of dikes (Grosfils and Head, 1994; Grindrod and others, 2005). Below, we describe two specific sets of lineaments: faults and fractures at coronae and those associated with Parga Chasmata.

\section{Coronae}

Fractures and faults, along with some ridges of possible compressional origin, make up the annuli surrounding coronae and are generally spaced tens of kilometers to a few kilometers apart. These are mapped representatively in red for emphasis. Some annuli, such as those at Anjea and Orbona Coronae, appear to have formed relatively early in the history of the corona, because they are embayed by flow material. Deformation at Ukemochi Corona is complex - interior deformation, followed by annulus formation, followed by another period of interior deformation - as indicated by crosscutting relations. Detailed mapping of individual coronae (Grindrod and Guest,
2006) is necessary to unravel the complex stages of annulus formation and volcanism.

The topography of the coronae has been classified following the scheme presented in Smrekar and Stofan (1997) (table 1). Seventeen of the coronae are plateaus or topographic highs, six are rimmed depressions, and three consist only of a topographic rim surrounding a flat interior. Four of the plateaushaped coronae have outer rises surrounding deep troughs that are proposed subduction trenches (Schubert and Sandwell, 1995).

\section{Rifts}

Radar-bright lineaments interpreted to be extensional faults and fractures associated with Parga Chasmata dominate the central portion of the map area, though most units in the map area exhibit some amount of fracturing. Parga Chasmata fractures are hundreds of kilometers long and vary in spacing from tens of kilometers to $<5 \mathrm{~km}$. Most are too narrow to be identified as graben. The rift fractures trend more or less east-southeast, parallel to the rift trough. Some of the fractures appear to be deflected around coronae, while others terminate at them.

Parga Chasmata extends for over 10,000 km from Atla Regio through Themis Regio. It is a discontinuous trough and fracture system with en echelon offset along strike that is characterized by numerous coronae along its length. Regions where the topographic trough is more distinct tend to be characterized by more closely spaced fractures (Martin and others, 2006), similar to Hecate Chasma (Hamilton and Stofan, 1996). The origin of chasmata systems is controversial, including theories ranging from extension and diapiric upwelling (Stofan and others, 1992; Hansen and Phillips, 1993; Bleamaster and Hansen, 2004) to subduction (Schubert and others, 1994; Schubert and Sandwell, 1995).

The Parga Chasmata rift consists of numerous branches; only the main branch of the rift is located in the map area. The rift trough varies in depth along the rift and, in most places, the zone of fracturing extends beyond the trough (Martin and others, 2007). In some places, the fractures or faults are very closely spaced, and in other places, the fractures are more widely spaced and tend to meander slightly.

The Parga Chasmata rift does extend across the Themis Regio rise but dies out in the plains to the east of Themis Regio. Most of the coronae in this region of the Parga Chasmata rift seem to have formed concurrently with rifting.

\section{Volcanic Features}

Six symbols are used in the map area for volcanic features: depression, volcanic edifice $>5 \mathrm{~km}$, steep-sided dome, volcanic edifice with diameter $<5 \mathrm{~km}$, flow direction, and channel. Channels are described in the Plains Material section above; both channels in the map area are in unit pm. Steep-sided domes are located throughout the map area and are discussed in more detail in the Volcanic Edifice and Flow Material section above. Two closed circular depressions (diameters $\sim 100$ and $50 \mathrm{~km}$ ) are seen at Angerona Tholus and in unit pm to the northeast of 
Angerona. Both of these features are interpreted to be calderas. Mielikki Mons also appears to have a summit caldera, but the lack of topographic expression suggests that it is filled with lavas. Hundreds of volcanic edifices $<5 \mathrm{~km}$ diameter (Head and others, 1992; Guest and others, 1992) are mapped in this quadrangle; where there is a distinct mappable boundary surrounding a cluster, they are mapped as edifice fields, as described above. In the map area, we used a circle with exterior hachures to designate volcanic edifices $>5 \mathrm{~km}$ diameter (not including steep-sided domes) that are too small to map at map scale. Flow direction symbols are used to illustrate distinct digitate flow paths.

\section{Geologic History}

The earliest geologic activity in the Themis Regio quadrangle $(\mathrm{V}-53)$ is recorded by plains units pdf and pl, which suggests that the region has been subjected to multiple episodes of plains-forming volcanism and deformation that culminated in the current (ongoing?) tectonic and volcanic activity at Parga Chasmata and Themis Regio. Unlike many other areas on Venus, the map area lacks regional-scale plains units. The scale of plains units tends to be on the order of hundreds rather than thousands of kilometers, and much of the region has been resurfaced by flows from volcanoes and coronae (Stofan and others, 2005). We have chosen to lump plains units of relatively similar morphology into units (for example, unit plT, unit pm) that are unlikely to have originated from the same source or have formed at the same time. It is also apparent that most of the volcanic units, including plains units such as units $\mathrm{pcH}$ and pm, corona units such as fD and fSh, and volcanic units such as $\mathrm{fTe}, \mathrm{fM}_{1}$, and $\mathrm{fM}_{2}$, are made up of multiple episodes of flow emplacement covering an undetermined amount of time. Their scale should not be interpreted to indicate a single resurfacing event (Romeo and Turcotte, 2009).

Because many units in the map area are not in contact, we are unable to confidently define the actual stratigraphic sequence, except for the events discussed below. This results in a Correlation of Map Units that shows a limited range in relative unit ages and uncertainty in the timing and extent of unit formation. For example, the observation that flows from Rigatona Corona overlie flows associated with both Erigone Corona and Anjea Corona has led us to place the latter two coronae at a relatively similar position in the Correlation of Map Units. However, we have no real insight into the relative unit ages between Anjea and Erigone Coronae, because their associated flow materials are not in contact. Therefore, a number of possible geologic histories could be developed for this quadrangle, most of which cannot be tested without age-dating surface rocks (Stofan and others, 2005).

Mapping of Themis Regio has permitted the delineation of some stratigraphic relations. Early-stage flows from Rigatona, Santa, and Semiramus Coronae overlie the mottled plains material (unit pm) to the north of Themis Regio, indicating that formation of these coronae generally postdated formation of these plains. Plains units originating from unknown sources within
Themis Regio (units plT, pfT) and generally overlain by corona deposits also overlie the unit pm, suggesting that rise formation in general has postdated formation of this unit. One patch of unit pm does lie on the northern margin of the rise, suggesting that this unit may have been partially uplifted during the formation of the rise. Corona flows also overlie plains units (units pm, $\mathrm{pcH}$ ) to the south, west, and east of Themis Regio, testifying to the potentially young age of the Themis rise.

Some stratigraphic relations among coronae can also be determined. Flows from Shiwanokia, the largest corona, overlie flows from Shulamite, Nzambi, Ama, and Ikas Coronae, while flows from Shulamite overlie flows from Latta, Erigone, and Rigatona Coronae and are overlain by flows from Santa Corona. Deposits from Ukemochi and Tamiyo interfinger (fig. 6), illustrating that formation of the two coronae overlapped in time. Older flows from Santa Corona (unit $\mathrm{fSa}_{1}$ ) are overlain by Durga Corona flow material (unit fD), but later Santa flows (unit $\mathrm{fSa}_{2}$ ) overlie Durga flows. The great complexity of the coronae in this region and their abundant volcanic deposits suggest long histories. For example, if flows from two coronae establish a relative age relation (such as the superposition of Shiwanokia flows over Nzambi flows), we cannot determine if the apparently older corona (Nzambi in this case) ceased all activity prior to emplacement of the younger flow from the other corona. In fact, the apparently older corona may have begun formation after the apparently younger feature but ceased activity sooner.

Age relations between coronae and volcanoes indicate that the two types of features formed throughout the history of the quadrangle. In some cases, volcanic flows are superposed on corona flows. For example, Chloris Mons flows overlie flows from Nzambi Corona, and flows from Abeona Mons overlie Ama Corona materials. Mielikki Mons flows overlie flows from Anjea, Durga, and Rigatona Coronae (fig. 7). At other locations, corona flows are younger. Gertjon Corona flows superpose Mielikki Mons flows, and Shiwanokia Corona materials overlie Abeona Mons materials. However, as with corona-to-corona age relations, we can only determine the relation between sets of flows; we cannot determine when each feature originated or the duration of activity. We see no clear evidence that coronae predate volcanoes, as suggested by McGovern and Solomon (1998).

A strong association between volcanism and coronae along rifts has been noted elsewhere on Venus (Magee and Head, 1995). In V-28 (Stofan and others, 2012) and V-53 map areas, some coronae along rifts do not have much associated volcanism; coronae with the most associated volcanism in these quadrangles are located at least $500 \mathrm{~km}$ off the rifts or on the Themis Regio highland. Whereas extension clearly plays a role in volcanism at coronae, it is not the only contributing factor (Martin and others, 2007). Coronae at Themis Regio may have greater than average associated volcanism owing to the possible mantle plume beneath the rise.

Individual coronae in Themis Regio have a range in complexity of morphology and in the amount of associated volcanism. In comparison to the other two corona-dominated rises (eastern Eistla Regio and central Eistla Regio), coronae at Themis Regio tend to have more associated flows, and no large volcanoes are located on the rise. Most of the coronae on 
the rise (Shiwanokia, Semiramus, Ukemochi) have undergone multiple stages of volcanism and deformation. At Ukemochi, interior deformation was followed by annulus formation, which in turn was followed by another episode of interior deformation. Initial Ukemochi flows that were more sheetlike have been followed by more digitate flows and the formation of an edifice on the annulus. This edifice has been subsequently deformed by continuing annular deformation. The complex, long-duration histories of these coronae are consistent with complex histories of coronae described by Copp and others (1998).

In the map area, we find no evidence to support a directional geologic history of Venus (Basilevsky and Head, 1995; Guest and Stofan, 1999). The directional model predicts that specific types of geologic units (coronae, small edifices) formed at distinct time periods (Basilevsky and Head, 1995, 1998). The Correlation of Map Units illustrates that all types of geologic activity, from large volcano formation to plains formation to corona formation, has occurred throughout the visible geologic history of this quadrangle. Overlapping episodes of corona, volcano, and plains formation have overlapped with episodes of dominantly extensional deformation. Evidence for several episodes of extensional deformation is provided by the rift, the lineated plains unit, and the deformed plains unit.

Smrekar and Stofan (1999) studied the morphology and gravity for the three corona-dominated rises on Venus, central and eastern Eistla Regiones and Themis Regio. Gravity data for Themis was best fit by a bottom-loading model with an elastic thickness estimate of $22 \mathrm{~km}$, a crustal thickness of $10 \mathrm{~km}$, and an apparent depth of compensation of 80-110 km. While the broad topographic rise and associated gravity anomaly at Themis Regio indicate the possible presence of an underlying plume, the complex sequence of corona formation favors formation by a series of small-scale upwellings over time rather than nearly simultaneously from the break-up of a single large-scale mantle plume (Smrekar and Stofan, 1999). This would indicate that buoyancy flux and plume duration are the primary factors controlling the difference between corona-dominated rises, such as Themis Regio, and volcano-dominated rises, such as Atla or western Eistla Regio. In addition, elastic and thermal lithospheric thicknesses that are estimated for Themis Regio are consistent with Earth-like values, and the range of stages of evolution of coronae, the delamination signal in the gravity data, and the broad topographic swell indicate that Themis Regio is likely to be underlain by an active plume with ongoing surface deformation due to delamination. The evidence for delamination at the coronae at Themis Regio is consistent with coronae contributing to heat loss on Venus through both upwellings and delamination and to the conclusion that lithospheric thickness is not a limiting factor on corona formation (Smrekar and Stofan 1997, 1999).

The geologic history of Themis Regio quadrangle (V-53) is dominated by volcanism and corona formation at Themis Regio and extensional deformation associated with Parga Chasmata, with interspersed episodes of plains formation. As shown in the Sequence of Map Units, all of this activity overlapped in time; however, the duration of the activity is unknown. Stofan and others (1995) suggested that Themis Regio is a hotspot underlain by a mantle plume. Terrestrial hotspots are thought to have lifetimes of hundreds of millions of years (Courtillot and others, 2003); we would expect Venusian hotspots to have relatively similar lifetimes. Given that the average crater-retention age of Venus is 750 m.y. (McKinnon and others, 1997) and that this region has previously been suggested to be relatively recently formed (Price and others, 1996; Smrekar and Stofan, 1999), it is possible that this region is still geologically active. Recent observations of the Themis Regio region by the Visual and Infrared Thermal Imaging Spectrometer instrument on the European Space Agency (ESA) Venus Express spacecraft (Mueller and others, 2008; Helbert and others, 2008) show a strong correlation between volcanic flows and high emissivity signatures that indicate possible unweathered surfaces and support possible ongoing formation of Themis Regio (Stofan and others, 2009; Smrekar and others, 2010).

\section{References Cited}

Addington, E.A., 2001, A stratigraphic study of small volcanoes on Venus: Icarus, v. 149, p. 16-36.

Baker, V.R., Komatsu, G., Parker, T.J., and three others, 1992, Channels and valleys on Venus-Preliminary analysis of Magellan data: Journal of Geophysical Research, v. 97, p. $13,421-13,444$.

Barsukov, V., Basilevsky, A.T., Burba, G.A., and 26 others, 1986, The geology and geomorphology of the Venus surface as revealed by the radar images obtained by Veneras 15 and 16: Journal of Geophysical Research, v. 91, no. B4, p. D378-D398.

Basilevsky, A.T., and Head, J.W., 1995, Global stratigraphic survey of Venus - Analysis of a random sample of thirtysix test areas: Earth, Moon and Planets, v. 66, p. 285-336.

Basilevsky, A.T., Pronin, A.A., Ronca, L.B., and 3 others, 1986, Styles of tectonic deformation on Venus-Analysis of Veneras 15 and 16 data: Journal of Geophysical Research, v. 91, p. 399-411.

Bleamaster, L.F., and Hansen, V.L., 2004, Effects of crustal heterogeneity on the morphology of chasmata, Venus: Journal of Geophysical Research, v. 109 (doi:1029/2003JE02193).

Campbell, B.A., 1995, Use and presentation of Magellan quantitative data in Venus mapping: U.S. Geological Survey Open-File Report 95-519, 36 p.

Copp, D.L., Guest, J.E., and Stofan, E.R., 1998, New insights into corona evolution-Mapping on Venus: Journal of Geophysical Research, v. 103, p. 19,410-19,418.

Courtillot, V., Davaille, A., Besse, J., and Stock, J., 2003, Three distinct types of hotspots in the Earth's mantle: Earth and Planetary Science Letters, v. 205, p. 295-308.

Crumpler, L.S., Aubele, J.C., Senske, D.A., and 3 others, 1997, Volcanoes and centers of volcanism on Venus, in Bougher, S.W., Hunten, D.M., and Phillips, R.J., eds., Venus IIGeology, geophysics, atmosphere and solar environment: Tucson, The University of Arizona Press, p. 697-756.

Ford, P.G., and Pettengill, G.H., 1992, Venus topography and kilometer-scale slopes: Journal of Geophysical Research, v. 97, p. 13,103-13,114. 
Ford, J.P., Plaut, J.J., Weitz, C.M., and 5 others, 1993, Guide to Magellan image interpretation: Pasadena, Calif., National Aeronautics and Space Administration Jet Propulsion Laboratory Publication 93-24, 287 p.

Grindrod, P.M., and Guest, J.E., 2006, 1:1,500,000 geological map of the Aglaonice region on Venus: UK, University of Kent, Journal of Maps, v. 2006, p. 103-117.

Grindrod, P.M., Nimmo, F., Stofan, E.R., and Guest, J.E., 2005, Strain as an indicator of multiple episodes of uplift and extrusion at radially fractured centers on Venus: Journal of Geophysical Research, v. 110 (doi:B0820210.1029/200 4JB003564).

Grosfils, E.B., and Head, J.W., 1994, The global distribution of giant radiating dike swarms on Venus-Implications for the global stress state: Geophysical Research Letters, v. 21, p. 701-704.

Guest, J.E., Bulmer, M.H., Aubele, J., and 6 others, 1992, Small volcanic edifices and volcanism in the plains of Venus: Journal of Geophysical Research, v. 97, p. 15,949-15,966.

Guest, J.E., and Stofan, E.R., 1999, A new view of the stratigraphic history of Venus: Icarus, v. 139, p. 55-66.

Hamilton, V.E., and Stofan, E.R., 1996, The geomorphology and evolution of Hecate Chasma, Venus: Icarus, v. 121, p. 171-194.

Hansen, V.L., 2000, Geologic mapping of tectonic planets: Earth and Planetary Science Letters, v. 176, p. 527-542.

Hansen, V.L., and DeShon, H.R., 2002, Geologic map of the Diana Chasma quadrangle (V-37), Venus: U.S. Geological Survey Geological Investigations Series I-2752, scale 1:5,000,000.

Hansen, V.L., and Phillips, R.J., 1993, Tectonics and volcanism of eastern Aphrodite Terra, Venus-No subduction, no spreading: Science, v. 260, p. 526-530.

Head, J.W., Crumpler, L.S., Aubele, J.C., Guest, J.E., and Saunders, R.S., 1992, Venus volcanism-Classification of volcanic features and structures, associations, and global distribution from Magellan data: Journal of Geophysical Research, v. 97, p. 13,153-13,197.

Helbert, J., Muller, N., Kostama, P., Marinangeli, M., Piccioni, G., and Drossart, P., 2008, Surface brightness variations seen by VIRTIS on Venus Express and implications for the evolution of the Lada Terra region, Venus: Geophysical Research Letters, v. 35, L11201 (doiL10.1029/2008GL033609).

Kasting, J.F., and Pollack, J.B., 1983, Loss of water from Venus 1-Hydrodynamic escape of Hydrogen: Icarus, v. 53, p. 479-508.

Koch, D.M., and Manga, M., 1996, Neutrally buoyant diapirsA model for Venus coronae: Geophysical Research Letters, v. 23 , p. $225-228$.

Komatsu, G., Baker, V.R., Gulick, V.C., and Parker, T.J., 1993, Venusian channels and valleys - Distribution and volcanological implications: Icarus, v. 102, p. 1-25.

Magee, K.P., and Head, J.W., 1995, The role of rifting in the generation of melt-Implications for the origin and evolution of the Lada Terra-Lavinia Planitia region of Venus: Journal of Geophysical Research, v. 100, p. 1527-1552.

Martin, P., Stofan, E.R., Glaze, L.S., and Smrekar, S.E., 2007,
Coronae of Parga Chasma, Venus: Journal of Geophysical Research, v. 112 (doi:10.1029/2006JE002758).

Masursky, H., Eliason, E., Ford, P.G., and 4 others, 1980, Pioneer-Venus radar results-Geology from images and altimetry: Journal of Geophysical Research, v. 85, p. 8232-8260.

McGill, G.E., 1993, Wrinkle ridges, stress domains, and kinematics of venusian plains: Geophysical Research Letters, v. 20, p. 2407-2410.

McGovern, P.J., and Solomon, S.C., 1998, Growth of large volcanoes on Venus-Mechanical models and implications for structural evolution: Journal of Geophysical Research, v. 103, p. 11,071-11,102.

McKenzie, D., Ford, P.G., Liu, F., and Pettengill, G.H., 1992, Pancake-like domes on Venus: Journal of Geophysical Research, v. 97, p. 15,967-15,976.

McKinnon, W.B., Zahnle, K.J., Ivanov, B.A., and Melosh, H.J., 1997, Cratering on Venus-Models and observations, in Bougher, S.W., Hunten, D.M., and Phillips, R.J., eds., Venus II-Geology, geophysics, atmosphere and solar environment: Tucson, The University of Arizona Press, p. 969-1014.

Mueller N., Helbert, J., Hashimoto, G.L., and 4 others, 2008, Venus surface thermal emission at 1 micron in VIRTIS imaging observations-Evidence for variation of crust and mantle differentiation conditions: Journal of Geophysical Research, v. 113, no. E00B17 (doi:10.1029/2008JE003118).

Pettengill, G.H., Ford, P.G., and Wilt, R., 1992, Venus surface radiothermal emission as observed by Magellan: Journal of Geophysical Research. v. 97, p. 13,091-13,102.

Phillips, R.J., Arvidson, R.E., Boyce, J.M., and 4 others, 1991, Impact craters on Venus-Initial analysis from Magellan: Science, v. 252, p. 288-297.

Plescia, J.B., and Golombeck, M.P., 1986, Origin of planetary wrinkle ridges based on study of terrestrial analogs: Geological Society of America Bulletin, v. 97, p. 1289-1299.

Price, M.H., Watson, G., Suppe J., Brankman, C., 1996, Dating volcanism and rifting on Venus using impact crater densities: Journal of Geophysical Research, v. 101, p. 46574672.

Romeo, I., And Turcotte, D.L., 2009, The frequency-area distribution of volcanic units on Venus-Implications for planetary resurfacing: Icarus, v. 203, p. 13-19.

Schubert, G., Moore, W.B., and Sandwell, S.T., 1994, Gravity over coronae and chasmata on Venus: Icarus, v. 112, p. 130-146.

Schubert G., and Sandwell, D.T., 1995, A global survey of possible subduction sites on Venus: Icarus, v. 117, p. 173-196.

Smrekar, S.E., and Stofan, E.R., 1997, Coupled upwelling and delamination-A new mechanism for coronae formation and heat loss on Venus: Science, v. 277, p. 1289-1294.

Smrekar, S.E., and Stofan, E.R., 1999, Origin of coronadominated topographic rises on Venus: Icarus, v. 139, p. 100-115.

Smrekar, S.E., Stofan, E.R., Mueller, N., and 5 others, 2010, Recent hot-spot volcanism on Venus from VIRTIS emissivity data: Science, v. 328, p. 305-308. 
Squyres, S.W., Jankowski, D.G., Simons, M., and 3 others, 1992, Plains tectonism on Venus - The deformation belts of Lavinia Planitia: Journal of Geophysical Research, v. 97, p. 13,579-13,610.

Stofan, E.R., Anderson, S.W., Crown, D.A., and Plaut, J.J., 2000, Emplacement and composition of steep-sided domes on Venus: Journal of Geophysical Research, v. 105, p. 26,757-26,772.

Stofan, E.R., Bindschadler, D.L., Head, J.W., and Parmentier, E.M., 1991, Corona structures on Venus-Models of origin: Journal of Geophysical Research, v. 96, p. 20,93320,946.

Stofan, E.R., Brian, A.W., and Guest, J.E., 2005, Resurfacing history of Venus - Evidence from 18 venusian quadrangles: Icarus, v. 173, p. 312-321.

Stofan, E.R., Brian, A.W., and J.E. Guest, J.E., 2012, Geologic map of the Hecate Chasma quadrangle (V-28), Venus: U.S. Geological Survey Geologic Scientific Investigations Map 3163, 1:5,000,000.

Stofan, E.R., and Guest, J.E., 2003, Geologic map of the Aino Planitia quadrangle (V-46), Venus: U.S. Geological Survey Scientific Investigations Map 2779, 1:5,000,000.

Stofan, E.R., Head, J.W., Campbell, D.B., and 5 others, 1989, Geology of a Venus rift zone-Beta Regio and Devana Chasma: Geological Society of America Bulletin., v. 101, p. 143-156.

Stofan, E.R., Sharpton, V.L., Schubert, G., and 4 others, 1992, Global distribution and characteristics of coronae and related features on Venus - Implications for the origin and relation to mantle processes: Journal of Geophysical Research, v. 97, p. 13,347-13,378.

Stofan, E.R., Smrekar, S.E., Bindschadler, D.L., and Senske, D.A., 1995, Large topographic rises on Venus-Implications for mantle upwelling: Journal of Geophysical Research., v. 100, p. 23,317-23,327.

Stofan, E.R., Smrekar, S.E., Helbert, J., Martin, P., and Mueller, N., 2009, Coronae and large volcanoes on Venus with unusual emissivity signatures in VIRTIS-Venus Express data: Lunar and Planetary Science Conference, Abstract \#1033.

Surkov, Yu. A., Barsukov, V.L., Moskalyeva, L.P., Kharyukova, V.P., and Kemurdzhian, A.L., 1984, New data on the composition, structure and properties of Venus rock obtained by Venera 13 and Venera 14: Journal of Geophysical Research, v. 89, p. B393-B402.

Tanaka, K.L, 1994, The Venus geologic mappers' handbook: U.S. Geological Survey Open-File Report 94-438, 48 p.

Wilhelms, D.E., 1972, Geologic mapping of the second planet: U.S. Geological Survey Interagency Report, Astrogeology, v. $55,36 \mathrm{p}$.

Wilhelms, D.E., 1990, Geologic mapping, in Greeley, R., and Batson, R.M., eds., Planetary mapping: New York, Cambridge University Press, 296 p.

Zahnle, K.J., 1992, Airburst origin of dark shadows on Venus: Journal of Geophysical Research, v. 97, p. 10,243-10,255.

Zimbelman, J.R., 2001, Image resolution and evaluation of genetic hypotheses for planetary landscapes: Geomorphology, v. 37, p. 179-199. 
Table 1. Coronae that produced deposits mapped in the Themis Regio quadrangle (V-53), Venus.

\begin{tabular}{|c|c|c|c|c|c|}
\hline $\begin{array}{l}\text { Coronae or } \\
\text { corona name }\end{array}$ & $\begin{array}{l}\text { Latitude } \\
\qquad\left({ }^{\circ} \mathrm{S}\right)\end{array}$ & $\begin{array}{l}\text { Longitude } \\
\qquad\left({ }^{\circ} \mathrm{E}\right)\end{array}$ & $\begin{array}{c}\text { Maximum } \\
\text { diameter }(\mathrm{km})\end{array}$ & Feature type* & Topography* \\
\hline Ama & -45.7 & 278.2 & 300 & concentric & rimmed plateau \\
\hline Anjea & -29 & 282.5 & 145 & concentric double ring & rim-inner high \\
\hline Bibi Patma (V-54) & -47 & 302 & 450 & concentric & plateau \\
\hline Durga & -31 & 286 & 227 & concentric & rim-inner high \\
\hline Erigone & -34.5 & 284 & 325 & multiple & partial rim \\
\hline Gertjon & -30 & 276 & 236 & concentric double ring & outer rise-trough-plateau \\
\hline Hutash & -34.5 & 275.2 & 91 & concentric & rimmed depression \\
\hline Ikas & -40.5 & 288.5 & 127 & multiple & rim only \\
\hline Latta & -38.7 & 287 & 200 & concentric double ring & rimmed depression \\
\hline Lilwani & -30.5 & 271.5 & 491 & asymmetric & outer rise-trough-plateau \\
\hline Navolga & -48.6 & 296.5 & 170 & concentric & rimmed depression \\
\hline Nzambi & -45 & 287.5 & 225 & asymmetric & rimmed plateau \\
\hline Obiemi & -31.9 & 276.6 & 300 & asymmetric & rimmed plateau \\
\hline Orbona & -47.5 & 293.5 & 182 & concentric & depression, partial rim \\
\hline Partula & -49.5 & 290 & 145 & concentric & depression, partial rim \\
\hline Parvati & -36 & 276.5 & 173 & concentric & rimmed depression \\
\hline Rigatona & -33.5 & 278.5 & 300 & concentric double ring & outer rise-trough-rimmed plateau \\
\hline Santa & -34.5 & 288 & 200 & $\mathrm{radial} /$ concentric & plateau \\
\hline Semiramus & -37 & 293 & 375 & asymmetric & plateau partial rim \\
\hline Shiwanokia & -42 & 279.8 & 409 & concentric & plateau \\
\hline Shulamite & -38.8 & 284.3 & 275 & concentric & plateau \\
\hline Tacoma & -37 & 288 & 500 & concentric & plateau \\
\hline Tamiyo & -36 & 298.5 & 400 & asymmetric & rim only \\
\hline Ukemochi & -39 & 296.1 & 300 & asymmetric & outer rise-trough-plateau \\
\hline Xmukane & -28.2 & 269.5 & 200 & radial/concentric & rim-trough-inner high \\
\hline Zywie & -38.6 & 291.2 & 200 & concentric & dome \\
\hline
\end{tabular}

*From Stofan and others, 1992. 
Table 2. Impact craters of Themis Regio quadrangle (V-53), Venus.

\begin{tabular}{lcccl}
\hline Crater Name & Latitude $\left({ }^{\circ} \mathbf{S}\right)$ & Longitude $\left({ }^{\circ} \mathrm{E}\right)$ & Diameter $(\mathbf{k m})$ & \multicolumn{1}{c}{ Unit } \\
\hline Peck & -28.9 & 294.3 & 30.4 & on/under pdf \\
Kitna & -28.9 & 277.3 & 15.3 & on pfT \\
Koinyt & -30.9 & 293.2 & 11.7 & on pm \\
Jocelyn & -33.2 & 276.4 & 14 & on $\mathrm{fO}_{1}$ \\
Maret & -33.3 & 280.2 & 11.7 & on $\mathrm{fR}$ \\
Elza & -34.4 & 275.9 & 18 & on $\mathrm{fO}_{1}$ \\
Sabin & -38.5 & 274.7 & 33.1 & on pm, $\mathrm{fS}_{1}$ \\
Aksentyeva & -42 & 271.9 & 42.5 & on plT \\
Kenny & -44.4 & 271.1 & 52.7 & under $\mathrm{fA}$ \\
Bernadette & -46.4 & 285.6 & 12.8 & on $/ \mathrm{under} \mathrm{fN}_{2}, \mathrm{fS}_{2}$ \\
Abington & -47.8 & 277.7 & 21.7 & on pm \\
Nastya & -49 & 275.8 & 12.5 & on pm \\
\hline
\end{tabular}

Table 3. Volcanoes of Themis Regio quadrangle (V-53), Venus.

\begin{tabular}{lcccl}
\hline \multicolumn{1}{c}{ Edifice Name } & Latitude $\left({ }^{\circ} \mathbf{S}\right)$ & Longitude $\left({ }^{\circ} \mathrm{E}\right)$ & Diameter $(\mathbf{k m})$ & \multicolumn{1}{c}{ Unit } \\
\hline Kwannon Tholus & -26.3 & 296.8 & 135 & unit $\mathrm{fK}$ \\
Ts'an Nu Mons & -27.2 & 272.9 & 310 & unit $\mathrm{fTs}$ \\
Mielikki Mons & -27.8 & 280.5 & 450 & units $\mathrm{fM}_{1}, \mathrm{fM}_{2}$ \\
Justitia Tholus & -28.7 & 296.5 & 60 & unit fJ \\
Angerona Tholus & -29.8 & 287.2 & 200 & unit fAn \\
Mertseger Mons & -38.1 & 270.3 & 450 & unit fMe \\
Tefnut Mons (V-54) & -38.6 & 304 & 182 & unit fTe \\
Rohina Tholus & -40.6 & 295.4 & 30 & unit fRh \\
Siduri Mons & -42.3 & 297.3 & 105 & unit $\mathrm{fSi}$ \\
Abeona Mons & -44.8 & 273.1 & 375 & unit $\mathrm{fA}$ \\
Chloris Mons & -45.4 & 294.6 & 180 & units $\mathrm{fC}_{1}, \mathrm{fC}_{2}$ \\
\hline
\end{tabular}


Table 4. Tabular version of the map unit relations in the Themis Regio quadrangle (V-53), Venus, shown in graphic format in the Correlation of Map Units. Unit age relations were determined by the identification of superposition relations and the use of cross-cutting structures.

\begin{tabular}{|c|c|c|c|}
\hline Unit Relations & Unit Name & Older Units & Younger Units \\
\hline \multirow{13}{*}{$\begin{array}{l}\text { Volcanic edifice and flow } \\
\text { material }\end{array}$} & fTs & pfT, pm & $\mathrm{fX}, \mathrm{plT}$ \\
\hline & $\mathrm{fSi}$ & pdf & $\mathrm{fU}_{e}, \mathrm{vc}, \mathrm{fC}_{1}$ \\
\hline & $\mathrm{fM}_{1}$ & $\mathrm{pl}, \mathrm{fD}$ & $\mathrm{fM}_{2}$ \\
\hline & $\mathrm{fM}_{2}$ & $f M_{1}, p m, p l, p f T, f A j, f R$ & $\mathrm{fG}_{1}$ \\
\hline & $\mathrm{fA}$ & pfT, plT, fAm & $\mathrm{fS}_{2}$ \\
\hline & $\mathrm{fC}_{1}$ & $\begin{array}{l}\text { pdf, pl, pm, plT, fSi, fU }, f N a, f_{1} \text {, } \\
f_{2}, f_{3}, f O r, \text { ef }\end{array}$ & $\mathrm{fC}_{2}$, ef \\
\hline & $\mathrm{fC}_{2}$ & $\mathrm{fC}_{1}, \mathrm{fB}_{2}, \mathrm{fOr}, \mathrm{ef}, \mathrm{pl}, \mathrm{fN}_{2}$ & \\
\hline & fAn & $\mathrm{pfT}$, ef, fD & \\
\hline & fTe & pfT, fUc, fTya & \\
\hline & $\mathrm{fMe}$ & pfT, pm, plT, fO 1 & \\
\hline & $\mathrm{fJ}$ & pdf, pm, ps, ef & \\
\hline & fK & pdf, ps & \\
\hline & $\mathrm{fRh}$ & $p l T, f Z, v c, f U_{a}, f U_{e}$ & \\
\hline \multirow[t]{26}{*}{ Corona flow material } & fIk & & $\mathrm{pm}, \mathrm{fN} \mathrm{N}_{2}, \mathrm{fTa}, \mathrm{fZ}, \mathrm{fSh}, \mathrm{fS} \mathrm{S}_{2}, \mathrm{fLt}, \mathrm{fSe}_{2}$ \\
\hline & $\mathrm{fNa}$ & pl & $\mathrm{fC}_{1}$, ef \\
\hline & fTa & fIk & $\mathrm{fSh}, \mathrm{fSa} \mathrm{a}_{2}, \mathrm{fSe} \mathrm{e}_{2}, \mathrm{fLt}, \mathrm{plT}$ \\
\hline & $\mathrm{fE}$ & & $f R$, ef, fSh, fSa ${ }_{1}, f D$ \\
\hline & $f S a_{1}$ & pfT, pm, plT, fE & $\mathrm{fD}, \mathrm{fSa}_{2}$ \\
\hline & $\mathrm{fSa}_{2}$ & $f S a_{1}, p f T, p m, p l T, f D, f T a, f E$ & $\mathrm{fSh}$ \\
\hline & $f A j$ & $\mathrm{pm}$ & $\mathrm{fM}_{2}, \mathrm{fR}$ \\
\hline & $\mathrm{fSe}_{1}$ & & $\mathrm{fSe}_{2}, \mathrm{fTy}_{\mathrm{a}}, \mathrm{fTy}_{\mathrm{c}}$ \\
\hline & $\mathrm{fSe}_{2}$ & pm, plT, fSe $1, f T a, f I k, f T y_{a}, f U_{a}$ & $\mathrm{fZ}$, ef \\
\hline & $\mathrm{fLt}$ & $\mathrm{fTa}, \mathrm{fIk}$ & fSh \\
\hline & $\mathrm{fN}_{1}$ & $\mathrm{pl}$ & $\mathrm{fN}_{2}$, ef, fOr \\
\hline & $\mathrm{fN}_{2}$ & $\mathrm{pl}, \mathrm{pm}, \mathrm{pcH}$, ef, flk & $\mathrm{c}, \mathrm{fC}_{2}, \mathrm{fS}_{1}, \mathrm{fS}_{2}$, ef \\
\hline & $\mathrm{fR}$ & $p f T, p m, f E, f A j$ & $c$, ef, $\mathrm{fO}_{1}, \mathrm{fO}_{3}, \mathrm{fM}, \mathrm{fG}_{1}, \mathrm{fSh}$ \\
\hline & $\mathrm{fD}$ & $\mathrm{pl}, \mathrm{pm}, \mathrm{pfT}, \mathrm{fSa} \mathrm{a}_{1}, \mathrm{fE}$ & $f A n$, ef, $\mathrm{fM}_{1}, \mathrm{fM}_{2}, \mathrm{fSa}_{2}$ \\
\hline & $\mathrm{fU}_{\mathrm{a}}$ & & $f U_{b}, f U_{c}, f U_{d}, f U_{e}, f R h, f T y_{a}, f S e_{2}, f Z$ \\
\hline & $\mathrm{fU}_{\mathrm{b}}$ & $f U_{a}, f Z$ & \\
\hline & $\mathrm{fU}_{\mathrm{C}}$ & $\mathrm{fU}_{\mathrm{a}}, \mathrm{pfT}, \mathrm{fTy}$ & $f T e, f U_{d}, f U_{e}$ \\
\hline & $f U_{d}$ & $\mathrm{fU}_{\mathrm{a}}, \mathrm{f} \mathrm{C}_{\mathrm{c}}$ & \\
\hline & $f U_{e}$ & $\mathrm{fU}_{\mathrm{a}}, \mathrm{fU} \mathrm{c}_{\mathrm{c}}, \mathrm{pfT}, \mathrm{plT}, \mathrm{vc}, \mathrm{fSi}$ & $\mathrm{fC}_{1}, \mathrm{fRh}$ \\
\hline & $\mathrm{fB}_{1}$ & pfT, plT & $\mathrm{fB}_{2}, \mathrm{fC}_{1}$, ef \\
\hline & $\mathrm{fB}_{2}$ & $\mathrm{fB}_{1}$, ef & $\mathrm{fB}_{3}, \mathrm{fC}_{1}, \mathrm{fC}_{2}$ \\
\hline & $\mathrm{fB}_{3}$ & $\mathrm{fB}_{2}$, ef & $\mathrm{fC}_{1}$ \\
\hline & fTya & $f S e_{1}, f S e_{2}$ & $f T e, f T y_{b}, f T y_{c}, f T y_{d}, f U_{c}$ \\
\hline & $\mathrm{fT} \mathrm{y}_{\mathrm{b}}$ & $\mathrm{fTy}_{\mathrm{a}}, \mathrm{pm}, \mathrm{plT}$ & $\mathrm{fTy}_{\mathrm{c}}$ \\
\hline & $\mathrm{fTy}_{\mathrm{c}}$ & $\mathrm{fTy}_{\mathrm{a}}, \mathrm{fTy}_{\mathrm{b}}, \mathrm{fSe}_{1}, \mathrm{pl}, \mathrm{plT}$ & $\mathrm{fTy}_{\mathrm{d}}$ \\
\hline & $\mathrm{fTy}_{\mathrm{d}}$ & $\mathrm{fTy}_{\mathrm{a}}, \mathrm{fTy}_{\mathrm{c}}$ & \\
\hline
\end{tabular}


Table 4. Tabular version of the map unit relations in the Themis Regio quadrangle (V-53), Venus, shown in graphic format in the Correlation of Map Units. Unit age relations were determined by the identification of superposition relations and the use of cross-cutting structures-continued.

\begin{tabular}{|c|c|c|c|}
\hline Unit Relations & Unit Name & Older Units & Younger Units \\
\hline & fOr & $\mathrm{pl}, \mathrm{fN}_{1}$ & $\mathrm{fC}_{1}, \mathrm{fC}_{2}$, ef \\
\hline & fAm & pm, plT & $f S_{2}, f A$ \\
\hline & $\mathrm{fZ}$ & $f e_{2}$, flk, pm, plT, fU & $f R h, v c, f U_{b}$ \\
\hline & $\mathrm{fO}_{1}$ & $\mathrm{fR}, \mathrm{plT}, \mathrm{pm}, \mathrm{pfT}$ & $c, v c, \mathrm{fO}_{2}, \mathrm{fO}_{3}, \mathrm{fMe}$ \\
\hline & $\mathrm{fO}_{2}$ & $\mathrm{pfT}, \mathrm{plT}, \mathrm{fO}_{1}$ & $\mathrm{vc}, \mathrm{fO}_{3}$ \\
\hline & $\mathrm{fO}_{3}$ & $\mathrm{fO}_{1}, \mathrm{fO}_{2}, \mathrm{pfT}, \mathrm{fR}$ & \\
\hline & $\mathrm{fS}_{1}$ & $\mathrm{pfT}, \mathrm{pm}, \mathrm{pcH}, \mathrm{fN}_{2}$ & $\mathrm{c}, \mathrm{fS}_{2}$ \\
\hline & $\mathrm{fS}_{2}$ & $\begin{array}{l}\mathrm{fS}_{1}, \mathrm{pcH}, \mathrm{pm}, \mathrm{pfT}, \mathrm{plT}, \mathrm{fAm}, \mathrm{fN}_{2}, \\
\mathrm{fA}, \mathrm{vc} \text {, fIk, fSh }\end{array}$ & c \\
\hline & $\mathrm{fG}_{1}$ & $\mathrm{pfT}, \mathrm{fM}_{2}, \mathrm{fR}$ & $\mathrm{fG}_{2}$ \\
\hline & $f G_{2}$ & $\mathrm{fG}_{1}, \mathrm{pfT}$ & \\
\hline & fSh & pfT, fIk, fLt, fTa, fSa2, fE, fR & $\mathrm{fS}_{2}, \mathrm{vc}$ \\
\hline & $\mathrm{fX}$ & $\mathrm{plT}, \mathrm{pm}, \mathrm{fTs}$ & $\mathrm{fL}$ \\
\hline & $f \mathrm{~L}$ & pm, plT, pfT, fX, fIk & \\
\hline \multirow[t]{7}{*}{ Plains material } & pdf & & $\mathrm{c}, \mathrm{ps}, \mathrm{pm}, \mathrm{fK}, \mathrm{fSi}, \mathrm{fJ}, \mathrm{vc}, \mathrm{ef}$ \\
\hline & $\mathrm{pl}$ & & $\begin{array}{l}\mathrm{fC}_{1}, \mathrm{fC}_{2}, \mathrm{fTyc}, \mathrm{fNa}, \mathrm{fOr}, \mathrm{fN}_{1}, \mathrm{fN}_{2}, \mathrm{pm}, \\
\mathrm{pcH}, \mathrm{ps}, \mathrm{pIT}, \mathrm{fO}, \mathrm{fM}_{1}, \mathrm{ef}, \mathrm{fM}_{2}, \mathrm{fSe}_{2}\end{array}$ \\
\hline & pfT & & 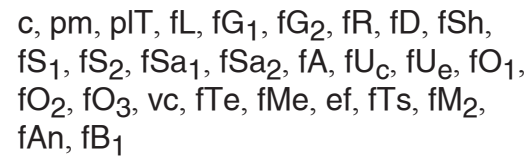 \\
\hline & $\mathrm{pm}$ & pdf, pl, pfT, fIk & $\begin{array}{l}\mathrm{c}, \mathrm{fM}_{2}, \mathrm{fTs}, \mathrm{fMe}, \mathrm{fC} \mathrm{C}_{1}, \mathrm{fR}, \mathrm{fSa}_{1}, \mathrm{fSa}_{2}, \\
\mathrm{fSe}_{2}, \mathrm{fD}, \mathrm{fL}, \mathrm{fX}, \mathrm{fO} \mathrm{f}_{1}, \mathrm{fAm}, \mathrm{fT} \mathrm{y}_{\mathrm{b}}, \mathrm{fS}{ }_{1}, \\
\mathrm{fS}_{2}, \mathrm{fZ}, \mathrm{fAj}, \mathrm{fN} \mathrm{N}_{2}, \mathrm{ef}, \mathrm{vc}, \mathrm{pcH}, \mathrm{ps}, \mathrm{plT}\end{array}$ \\
\hline & $\mathrm{pcH}$ & $\mathrm{pm}, \mathrm{pl}$ & $\mathrm{fS}_{1}, \mathrm{fS}_{2}, \mathrm{fN}_{2}$ \\
\hline & $\mathrm{plT}$ & $\mathrm{pfT}, \mathrm{pm}, \mathrm{pl}$, & 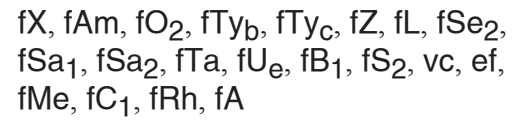 \\
\hline & ps & pm, pdf & $\mathrm{fK}, \mathrm{fJ}$ \\
\hline
\end{tabular}

